\author{
Svitlana ISHCHUK, \\ Liudmyla KOVAL
}

\title{
DEVELOPMENT OF CHEMICAL INDUSTRY IN UKRAINE AND THE WORLD: COMPARATIVE ESTIMATION
}

\begin{abstract}
The main trends of the chemical industry development in globalization changes terms are investigated. The share of Ukraine in chemical products export of TOP-10 world chemical market participants and the European Union countries is determined. A comparative estimation of chemicals and pharmaceuticals production dynamics, as well as the structure of foreign trade (export / import) of these products in Ukraine and the EU-28 is conducted. The prospects for the domestic chemical industry development are outlined based on the calculation of Ukrainian and the EU members chemical enterprises main functioning indicators. The measures for innovation activity activation and the institutional reforms in Ukraine on purpose of the chemical production competitiveness increasing are proposed.
\end{abstract}

(C) Svitlana Ishchuk, Liudmyla Koval, 2019.

Ishchuk Svitlana, Dr. Sc. (Econ.), Professor, Head of the Department of problems of real sector of regions economy, SI «Institute of Regional Research n.a. M.I. Dolishniy of the NAS of Ukraine», Lviv, Ukraine. e-mail: iso.ird@ukr.net. ORCID ID 0000-0002-3698-9039.

Koval Liudmyla, Ph.d (Econ.), associate professor, Senior Researcher of the Department of problems of real sector of regions economy, SI «Institute of Regional Research n.a. M.I. Dolishniy of the NAS of Ukraine», Lviv, Ukraine. e-mail:myla_k@ukr.net. ORCID ID 0000-0002-0285-3264. 


\section{Key words:}

Chemical industry, chemicals, pharmaceuticals, exports, imports.

JEL: L690, O570.

\section{Introduction}

The chemical industry is one of the leading global industry segment. For example, in the US and the EU, chemical production accumulates the highest share of value added (16\%) created in industry. In 2018, the share of chemicals production in the US reached $13.6 \%$ of the total industrial production in the country. In the EU, the chemical sector, which involved $12 \%$ of the employed in industry and mastered the largest volume of investment in industrial production (18\%), accounted for $7.6 \%$ of sold industrial products (EU chemical industry production, electronic resource).

Producing intermediate consumption products (raw materials and semifinished products) for all sectors of the economy, modern chemical industry determines largely the level of their competitiveness, as well as the development dynamics and the innovation processes direction. On the other hand, the wide assortment of household chemical products confirms its weight on the consumer market. The level of "chemigration" is a universally accepted criterion for the socio-economic development of any country. Thus, in industrialized countries, chemicals production shares from $5-8 \%$ to $13-16 \%$ in industry, while in Ukraine less than $3 \%$. Ukrainian chemical production is export oriented (the share of exports in the volume of sold chemical products in 2017 was $60 \%$ ) and, at the same time, import-dependent (the share of imports in the intermediate consumption of chemicals and chemical products is $>95 \%$ ), and, consequently, dynamics and results their functioning depends directly on the situation on the world market of chemical products.

Due to the key role of the chemical industry in balanced socio-economic development supporting, this sector become the subject of systematic researches. Thus, a scientists team of the Institute of Industrial Economics assessed the chemicals and chemical products manufacture main indicators, and 
identified two strategic directions for the domestic chemical industry development in the neo-industrial concept implementation (Amosha, Buleyev, Zaloznova, p. 302-305, 2017). The problem of European chemical clusters functioning and the prospects for their creation in Ukraine is detailed in (Shevtsova, Shvets, 2017). The scientists of the Institute of Economics and Forecasting have thoroughly investigated the Agreement on the Free Trade Area provisions implementation and the its prospects for the chemicals production development in Ukraine, in particular in the direction of the export potential increasing and import substitution (Heyets, Ostashko, p. 69-80, 2016). The assessment of the basic chemistry and fertilizers market was carried out in (Deyneko, p. 43-47, 2018).

Currently, the chemical industry 4.0 (Chemicals 4.0 ) is actively forming in the world, which can be considered as a branch concept of the Fourth Industrial Revolution foundations implementation. This concept is intended to become a leading strategic benchmark for bringing chemical technologies, industries and markets to a fundamentally new level thanks to the systematic use of «smart» innovations and information and communication technologies. The content and features of the of the industry 4.0 concept in the chemical industry are covered in (Shevtsova, 2017). Ukraine also needs to develop and implement a new model for the development of the chemical industry, which would meet modern global neo-industrial changes and challenges within the industry 4.0. But the solution to this problem is rather problematic, primarily due to the high resource and energy intensity of the domestic chemical industry, caused by the low technological level of production, the critical state of fixed assets and the lack of innovative activity of enterprises and many other factors, both external and internal.

The purpose of the article is to determine the place of the chemical industry of Ukraine among the main participants of the world market of chemical products, in particular, the countries of the European Union.

\section{Research results}

The Ukrainian chemical industry is directly influenced by the consequences of the chemical products world market competitive environment transformation, which has intensified since 2015. Among the world chemical industry development key trends over the past 4 years, one can distinguish the following:

1. Mergers and acquisitions. In 2015, the merger of Dow and DuPont took place, and in 2016 it was purchased by the Chinese national company ChemChina of Syngenta Corporation (the world's largest producer of plant and seed and plant protection products), as well as the conclusion of an agreement between the German Concern Bayer and the American producer of genetically 
modified seeds and herbicide Monsanto. These megazlites are caused by a number of factors, namely:

- falling prices for grain and slow growth of the agricultural segment of the world economy;

- the need to increase the resource base in the most promising agrosectors;

- the desire to increase the efficiency of chemical production, in particular, by using opportunities to attract low-cost financing.

2. New regulatory environment formation. In particular, the Lauthenberg Act was passed, which sets out a single standard (plus the requirements of existing state and local regulations) regarding the safety of chemical production in the world.

3. Investment activation. First of all, it concerns North America, where a large wave of multibillion-dollar investments in new production facilities of chemical production took place.

4. The introduction of innovative technologies designed to reduce costs for producers, as well as create new business models that would help to establish relationships between chemical manufacturers with suppliers, their direct customers and end users. Thus, due to the automation and use of IloT (Industrial Internet of Things), the operational and business environment in the chemical industry undergoes radical changes, in particular: the practice of embedding intelligent sensors in production capacities that control performance or transmit data to object managers is introduced to identify optimal operating conditions and the need for preventive maintenance; automation has been applied to improve the safety of workers of chemical plants, etc.

According to experts from the international corporation GeneralElectric, today the world chemical industry is undergoing more radical changes than at any given time in the last 40-50 years, and the pace of these changes continues to grow (The industry is undergoing more disruptive change than perhaps at any point in the past 40 to 50 years, and the pace of this change continues to intensify, electronic resource).

In 2017, world chemicals production grew by $3.5 \%$ compared with the previous year, in particular: in the EU-28 by $3.8 \%$ (vs. $0.4 \%$ ), in the US - by $2.9 \%$ (vs. $1.0 \%$ ), in Japan - by $7.2 \%$ (vs. $1.7 \%$ ), in Asia - by $3.8 \%$ (vs. $5.8 \%$ ) (Trends in the chemical industry, electronic resource). As a result, the EU-28 remained the world leader in the chemical industry, primarily due to the chemicals export, which grew by $6.2 \%$ in 2017 compared to the previous year, with a positive trade balance of EUR 138.35 billion (vs. 128.41 in addition to the EU-28, in 2017, the United States and China (authors' calculations) were among the top three exporters on the world market for chemical products in 2017. 
The share of Ukraine in chemicals export to the top 10 participants in the world chemical market was the highest in 2011, however, since 2012 there is an annual decrease in the values of this indicator (Table 1).

Table 1

The share of Ukraine in the export of chemical products of the top 10 participants in the world chemical market, \%

\begin{tabular}{|l|c|c|c|c|c|c|c|c|}
\hline Країна & 2010 & 2011 & 2012 & 2013 & 2014 & 2015 & 2016 & 2017 \\
\hline EU-28 & 1.08 & 1.47 & 1.36 & 1.15 & 0.84 & 0.63 & 0.45 & 0.40 \\
\hline USA & 1.70 & 2.42 & 2.28 & 1.93 & 1.45 & 1.04 & 0.80 & 0.74 \\
\hline China & 3.68 & 4.40 & 4.16 & 3.36 & 2.27 & 1.64 & 1.27 & 0.76 \\
\hline Japan & 4.22 & 6.12 & 6.16 & 5.41 & 4.31 & 3.47 & 2.48 & 2.15 \\
\hline South Korea & 6.53 & 8.22 & 7.67 & 6.07 & 4.50 & 3.63 & 2.63 & 2.18 \\
\hline Canada & 9.71 & 12.79 & 12.78 & 10.68 & 8.08 & 5.84 & 4.58 & 4.40 \\
\hline Singapore & 8.07 & 9.75 & 8.71 & 8.03 & 5.77 & 4.55 & 3.39 & 3.31 \\
\hline India & 12.29 & 14.62 & 11.24 & 9.06 & 7.62 & 5.72 & 4.13 & 3.73 \\
\hline Mexico & 27.44 & 35.99 & 31.18 & 26.28 & 19.86 & 15.13 & 11.80 & 12.01 \\
\hline
\end{tabular}

Author's calculations by (State Statistics Service of Ukraine; UN Comtrade Database, electronic resource)

The share of Ukraine in compare to EU-28 chemicals export in 2017 was only $0.4 \%$ (compared to $1.47 \%$ in 2011). Ukrainian chemicals export in compare to the leading EU chemical producers is also minor, in particular: $1.7 \%$ of German chemicals export in 2016-2017 and less than 5\% in France, Belgium, Ireland (Table 2). In addition, during this period, Ukraine exported substantially less chemical products than such post-socialist countries as Poland, Slovenia, Hungary and the Czech Republic.

The EU chemical industry leader is Germany, which produces $1 / 4$ of world chemical products, and also takes 2 nd place - in terms of its exports. The share of Germany in EU-28 chemicals export was $27 \%$ in 2017 . The next countries were also included to the top $10 \mathrm{EU}-28$ by the share of chemicals export: France $-11.2 \%$, Belgium $-10.5 \%$, Ireland $-10.3 \%$, United Kingdom - $8.6 \%$, the Netherlands $-7.2 \%$, Italy $-6.9 \% \%$, Spain $-4.6 \%$, Denmark - 3.1\%, Sweden $-2.5 \%$ (author's calculations by State Statistics Service of Ukraine; Annual detailed enterprise statistics for industry, electronic resource). 
Table 2

Ukrainian chemicals export in compare to the EU countries, \%

\begin{tabular}{|l|c|c|c|c|c|c|c|c|}
\hline Country & 2010 & 2011 & 2012 & 2013 & 2014 & 2015 & 2016 & 2017 \\
\hline Austria & 45.4 & 61.0 & 59.2 & 48.9 & 35.9 & 29.5 & 20.2 & 21.7 \\
\hline Belgium & 8.2 & 12.3 & 10.7 & 9.4 & 7.3 & 5.6 & 4.1 & 4.2 \\
\hline Bulgaria & 334.1 & 427.5 & 412.0 & 347.0 & 246.4 & 201.6 & 172.3 & 157.6 \\
\hline $\begin{array}{l}\text { United King- } \\
\text { dom }\end{array}$ & 8.9 & 13.5 & 12.9 & 11.9 & 9.1 & 5.3 & 4.7 & 5.2 \\
\hline Greece & 333.1 & 532.2 & 528.6 & 405.1 & 306.4 & 250.0 & 187.5 & 178.1 \\
\hline Denmark & 44.1 & 60.5 & 49.4 & 38.1 & 28.4 & 20.1 & 13.7 & 14.3 \\
\hline Estonia & 1157.8 & 1107.3 & 935.8 & 875.8 & 753.8 & 755.6 & 526.4 & 484.6 \\
\hline Ireland & 10.6 & 14.1 & 15.8 & 13.0 & 9.2 & 5.9 & 4.1 & 4.3 \\
\hline Spain & 24.0 & 33.0 & 30.7 & 23.5 & 17.1 & 13.3 & 9.9 & 9.7 \\
\hline Italy & 16.3 & 22.1 & 21.3 & 16.9 & 13.4 & 10.5 & 7.2 & 6.4 \\
\hline Cyprus & 1981.1 & 3103.6 & 2509.8 & 2053.7 & 1590.9 & 1165.1 & 850.4 & 834.5 \\
\hline Latvia & 919.4 & 1187.5 & 1062.7 & 874.8 & 623.3 & 545.4 & 347.4 & 313.1 \\
\hline Lithuania & 370.8 & 435.4 & 390.2 & 321.7 & 238.0 & 182.8 & 120.1 & 109.4 \\
\hline Lithuania & 813.4 & 1088.6 & 1243.0 & 1078.8 & 865.8 & 683.2 & 497.1 & 464.5 \\
\hline Luxembourg & 3907.5 & 5479.4 & 6758.8 & 5053.3 & 2972.0 & 1332.7 & 882.5 & 829.4 \\
\hline Malta & 2677.4 & 4015.4 & 3846.0 & 2689.3 & 2041.4 & 1468.4 & 194.9 & 1617.0 \\
\hline Netherlands & 16.7 & 19.3 & 17.8 & 15.2 & 11.6 & 8.8 & 6.8 & 6.2 \\
\hline Germany & 4.3 & 5.9 & 5.4 & 4.3 & 3.2 & 2.4 & 1.7 & 1.7 \\
\hline Poland & 80.1 & 108.5 & 94.3 & 74.1 & 59.5 & 49.7 & 34.0 & 30.7 \\
\hline Portugal & 344.5 & 369.9 & 366.1 & 299.6 & 206.6 & 169.0 & 124.8 & 127.1 \\
\hline Romania & 286.6 & 296.5 & 292.6 & 280.3 & 223.1 & 217.2 & 166.1 & 155.4 \\
\hline Slovenia & 195.4 & 250.3 & 228.5 & 169.9 & 126.6 & 110.8 & 84.4 & 82.9 \\
\hline Hungary & 125.4 & 173.0 & 149.5 & 111.8 & 97.2 & 80.4 & 60.4 & 51.3 \\
\hline Finland & 126.6 & 164.6 & 164.7 & 143.2 & 116.6 & 75.4 & 59.7 & 57.9 \\
\hline France & 8.6 & 11.9 & 11.3 & 9.3 & 7.2 & 5.5 & 4.1 & 4.0 \\
\hline Croatia & 447.1 & 574.7 & 570.3 & 495.3 & 404.1 & 320.7 & 181.9 & 161.1 \\
\hline $\begin{array}{l}\text { Czech } \text { Re- } \\
\text { public }\end{array}$ & 174.6 & 235.3 & 219.7 & 186.2 & 145.0 & 122.0 & 93.5 & 91.9 \\
\hline Sweden & 42.6 & 58.9 & 55.1 & 43.9 & 34.8 & 24.9 & 18.8 & 18.1 \\
\hline Aunor's & & & & & & & & \\
\hline
\end{tabular}

Author's calculations by (State Statistics Service of Ukraine; Annual detailed enterprise statistics for industry, electronic resource)

The largest volumes of chemical production (in value terms) in the EU-28 were achieved in 2015, which in turn caused an increase in exports with virtually the same level of chemicals import. In 2017, there was a slight increase in 
chemicals production (by $1.5 \%$, as compared to the previous year), as well as by a substantial increase (by $6.2 \%$ ) in export.

By 2013, the trends of the chemical industry in Ukraine and in the EU-28 were the same: the decline in chemicals production in 2007-2009, growth in 2010 and the decline in 2012 (Fig. 1).

Fig. 1

The growth (decrease) of chemicals and pharmaceuticals manufacture in Ukraine and the EU-28, \% to the previous year

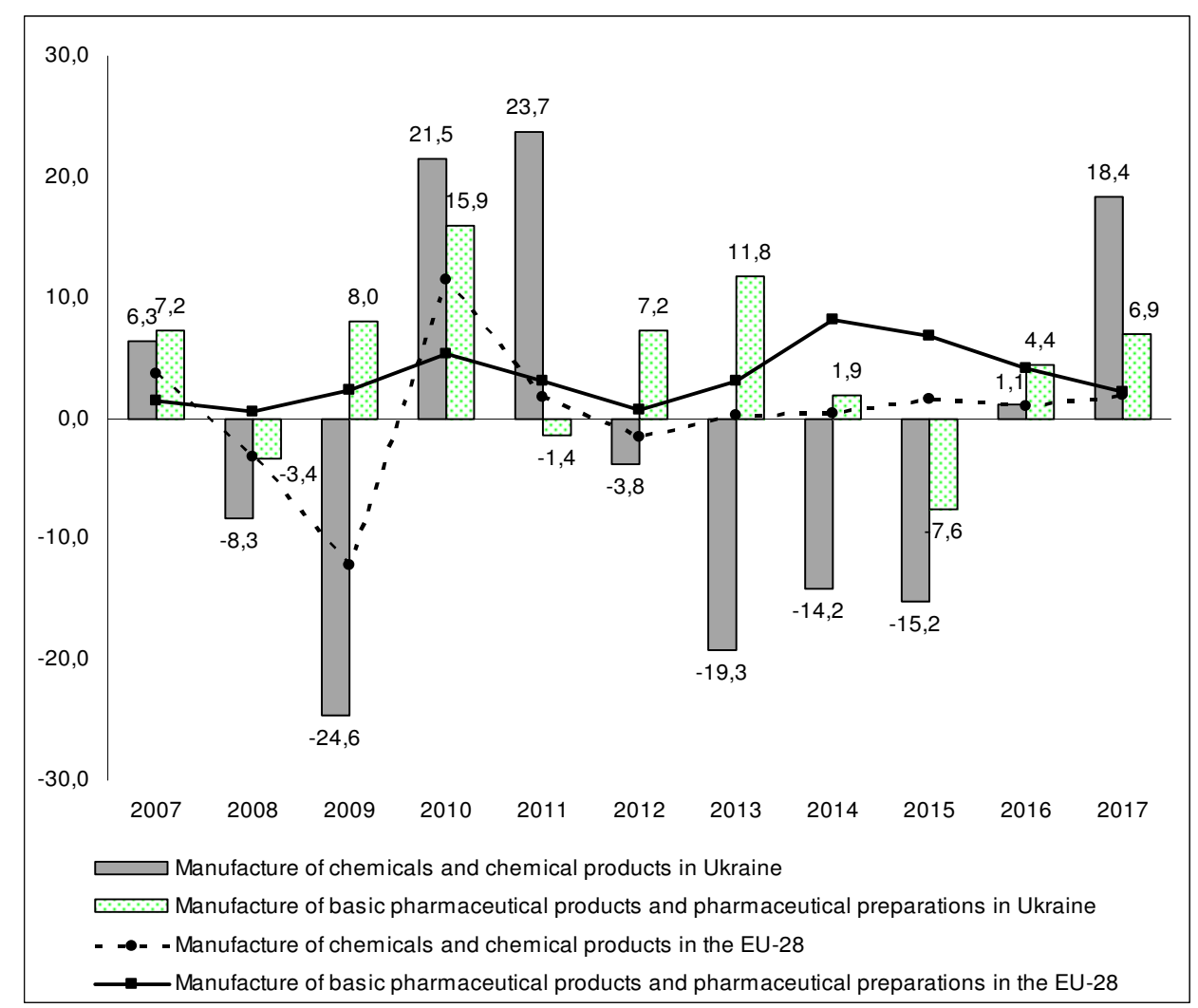

Built by (State Statistics Service of Ukraine; Annual detailed enterprise statistics for industry, electronic resource) 
ISSN 2519-4070

During 2013-2015, the chemical industry development trends had been changed. So, when there was a slight increase in the chemicals production (from $0.2 \%$ in 2013 to $1.5 \%$ in 2015) in the EU-28, in Ukraine there was a significant decrease (from -19.3\% in 2013 to $-15.2 \%$ in 2015). Instead, in 2017, the chemicals production in Ukraine grew by $18.4 \%$, while the production of basic pharmaceuticals and pharmaceuticals increased by $6.9 \%$, whereas in the EU-28 the growth of these indicators was only $1.8 \%$ and $2.1 \%$ respectively. This has been evidence of a higher (compared with the EU chemical industry) domestic chemical industry vulnerability to the external and internal environment changes.

Against the backdrop of accelerating growth in the chemicals production in the EU-28 in 2017, the slowdown in the growth rate of high-tech basic pharmaceuticals and pharmaceuticals manufacturing began in 2015 and dropped to $2.1 \%$ (vs. $8.1 \%$ in 2014). However, despite the negative trends in production, pharmaceutical products are dominant in foreign trade compared to other chemical products. Thus, in 2017 , this commodity sub-group accounted for $47 \%$ of exports and $39 \%$ of EU-28 chemical imports, while demonstrating the highest average annual growth rates of exports and imports for $2007-2017-8.8 \%$ and $8.7 \%$ respectively (Table 3).

The largest pharmaceutical manufacturers in Europe are Switzerland (25.9\% of the total EU-28 pharmaceutical production in 2016), Germany $(16.8 \%)$, France (13.4\%), Italy (9.5\%), Belgium (8.6\%), Denmark (5.1\%), Spain $(4.7 \%)$. The highest rate of growth was in Greece (17.9\%), Romania (15.2\%), Norway (13.7\%), Denmark (12.1\%), the Czech Republic (10.6\%), Switzerland (10.5\%), while in Germany, France, Italy, Spain and Belgium, the value of this indicator was significantly lower $(5.5 \%, 5.3 \%, 6.3 \%, 2.8 \%$, and $3.4 \%$ respectively). High rates of foreign trade are also typical for organic chemicals, which occupied $13.3 \%$ of exports and $23.1 \%$ of EU chemicals import in 2017.

The volume of chemical products domestic exports in the EU-28 exceeds the volume of external exports, which means a greater orientation of producers to the domestic market of the EU than to foreign markets. The largest gap between the volumes of domestic and foreign exports is observed in such commodity subgroups as fertilizers (in 2017 the volume of domestic exports exceeded the volume of external exports by 2.3 in times) and plastics in primary forms (by 2.8 in times) (Fig. 2). At the same time, the volume of domestic exports of the largest commodity subgroup - organic chemistry - was only $9 \%$ higher than the volume of external exports, indicating the manufactures orientation to the same extent both on the domestic EU market and on the external market.

The structure of chemical products foreign trade in Ukraine differs from the similar EU-28 structure. So, when in the EU the priority is export of pharmaceuticals (46.95\% in 2017) and organic chemical compounds (13.31\%), in Ukraine the main part of exports is taken by products of inorganic chemistry (47.0\%). Fertilizers, which are the second largest pharmaceutical importer in Ukraine $(17.2 \%$ in 2017), in the similar structure of EU-28 imports, occupy the smallest share 
(2.2\%) among all product subgroups. At the same time, the commodity structure of chemical products export in Ukraine is being transformed in the direction of approaching to structure of the EU-28: it increases the pharmaceuticals and organic chemicals export share. The common feature of chemical products import structure in Ukraine and the EU-28 is the dominance of pharmaceuticals share, which value in 2017 accounted for $27.0 \%$ and $39.4 \%$, respectively.

Table 3

Commodity structure of foreign trade in chemical products in Ukraine and EU-28

\begin{tabular}{|l|c|c|c|c|c|c|c|c|c|c|}
\hline \multirow{2}{*}{$\begin{array}{c}\text { Commodity } \\
\text { subgroup }\end{array}$} & \multicolumn{5}{|c|}{ EU } & \multicolumn{5}{c|}{ Ukraine } \\
\cline { 2 - 10 } \% in the structure of export of chemical products \\
\hline $\begin{array}{l}\text { Organic chemi- } \\
\text { cals }\end{array}$ & 15.59 & 15.63 & 15.09 & 13.31 & 5.05 & 3.12 & 4.40 & 8.50 \\
\hline $\begin{array}{l}\text { Inorganic chemi- } \\
\text { cals }\end{array}$ & 3.17 & 3.01 & 2.78 & 2.87 & 38.58 & 45.40 & 40.50 & 47.00 \\
\hline $\begin{array}{l}\text { Pharmaceutical } \\
\text { products }\end{array}$ & 42.43 & 45.26 & 45.92 & 46.95 & 8.37 & 7.29 & 11.82 & 11.57 \\
\hline $\begin{array}{l}\text { Essential oils, } \\
\text { resinoids and } \\
\text { perfume materi- } \\
\text { als }\end{array}$ & 9.76 & 9.34 & 9.66 & 9.71 & 5.73 & 5.00 & 5.99 & 6.58 \\
\hline Fertilizers & 0.97 & 1.01 & 0.85 & 0.86 & 22.74 & 25.06 & 21.06 & 7.78 \\
\hline & in the structure of import of chemical products \\
\hline $\begin{array}{l}\text { Organic chemical } \\
\text { compounds }\end{array}$ & 24.24 & 24.31 & 22.82 & 23.12 & 10.46 & 11.36 & 9.69 & 9.32 \\
\hline $\begin{array}{l}\text { Inorganic Chem- } \\
\text { istry Products }\end{array}$ & 7.78 & 7.08 & 5.96 & 5.94 & 4.51 & 5.67 & 5.44 & 5.79 \\
\hline $\begin{array}{l}\text { Pharmaceutical } \\
\text { products }\end{array}$ & 38.06 & 38.98 & 40.74 & 39.40 & 36.47 & 27.29 & 28.60 & 27.00 \\
\hline $\begin{array}{l}\text { Essential oils, } \\
\text { resinoids and } \\
\text { perfume materi- } \\
\text { als }\end{array}$ & 4.53 & 4.78 & 5.11 & 5.11 & 10.46 & 9.81 & 9.29 & 9.16 \\
\hline Fertilizers & 2.53 & 2.52 & 2.15 & 2.20 & 8.74 & 14.14 & 14.64 & 17.21 \\
\hline
\end{tabular}

Author's calculations by (State Statistics Service of Ukraine; Annual detailed enterprise statistics for industry, electronic resource) 
Fig. 2

Foreign chemical products trade in EU-28 in 2017, EUR million

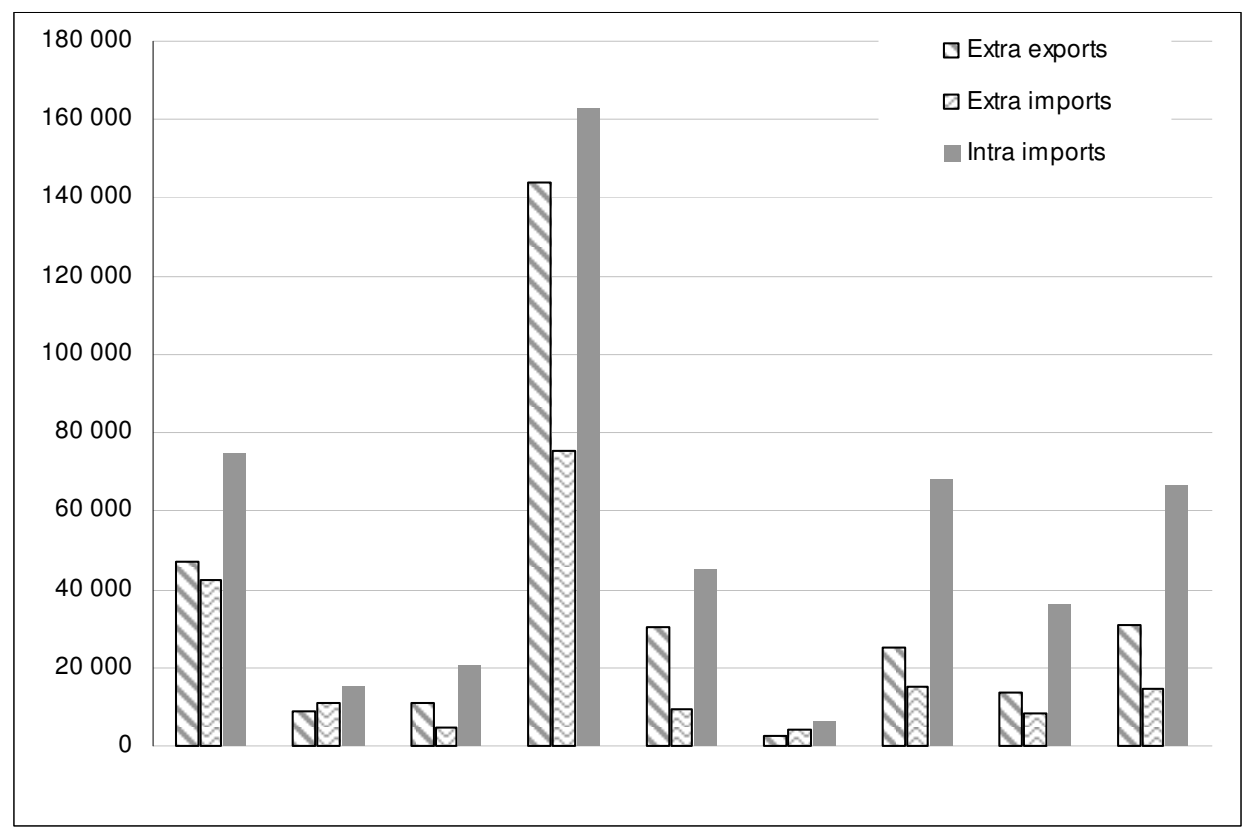

51- Organic chemicals

52- Inorganic chemicals

53- Dyeing, tanning\&colouring materials

54-Medical and pharmaceutical products

55- Essential oils, resinoids and perfume materials

56- Fertilizers (other than those of group 272)

57- Plastics in primary forms

58- Plastics in non-primary forms

59-Chemical materials and products

Built by (Annual detailed enterprise statistics for industry, electronic resource)

For the indicators of the chemical products foreign trade dynamics EU-28 is characterized by higher stability, compared with Ukraine. Thus, in particular, if the EU-28 is undergoing an annual increase in the volume of chemicals export, the tendency for export growth was observed in Ukraine until 2012 and recovered only in 2016-2017 years (Fig. 3). As a result, the volume of chemical products Ukrainian exports of in 2017 amounted to only $40.2 \%$ of its volume in 2012 , while the EU-28 exports increased by $20.9 \%$ over this period. 
Fig. 3

Dynamics of chemical products export and import in Ukraine and EU-28

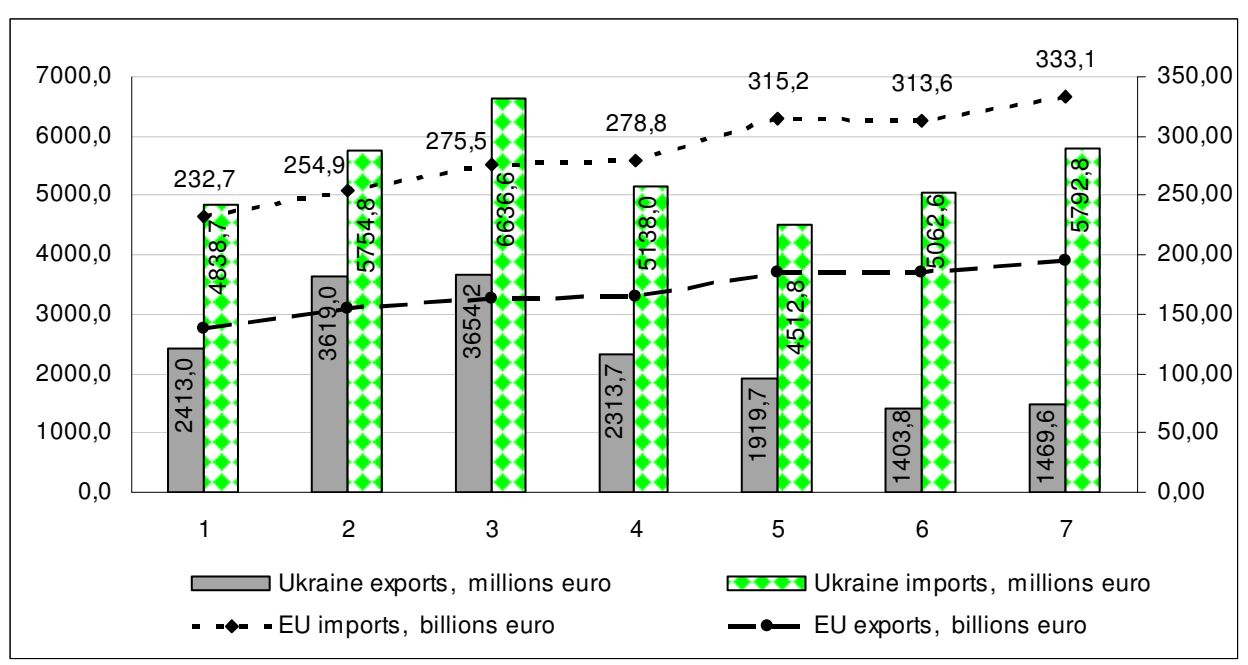

Built by (State Statistics Service of Ukraine; Annual detailed enterprise statistics for industry, electronic resource)

According to the results of author's calculations carried out on the basis of the data of the State Statistics Service of Ukraine (State Statistics Service of Ukraine, electronic resource) and Eurostat (Annual detailed enterprise statistics for industry, electronic resource), the chemicals import trends in the EU countries (which are characterized by stable insignificant growth), correlate with the trends of export performance. While in Ukraine, after a tangible decrease in chemical products import (by $32 \%$ during 2014-2015), since 2016, its intensive growth is taking place.

Low values of performance indicators are typical for Ukrainian chemical industry (in particular, in the production of chemicals) (Table 4). Thus, according to the number of chemical enterprises, Ukraine is second only to the UK, Spain, Italy, Germany, France and Poland, which are the leaders of the chemical industry development in the EU. Instead, the volume of chemical products sales per one chemical enterprise in Ukraine (0.97 million EUR in 2016) is significantly lower than in the EU countries. Thus, in particular, this indicator in Belgium was higher than in Ukraine, almost in 62 times, and in Poland - in 6.3 in times. 
Table 4

Indicators of the functioning of the chemical industry (production of chemicals and chemical products) in Ukraine and the EU countries in 2016

\begin{tabular}{|c|c|c|c|c|c|c|}
\hline Country & 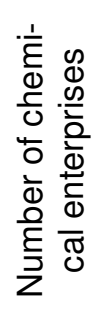 & 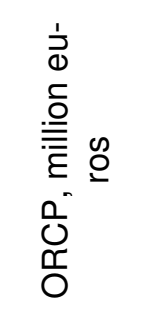 & 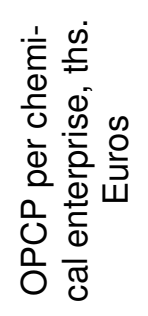 & 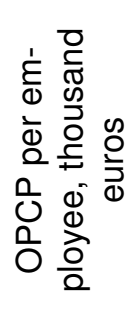 & 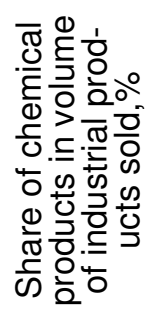 & 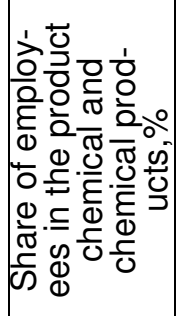 \\
\hline Ukraine & 2046 & 1987.7 & 971.5 & 28.4 & 2.6 & 2.9 \\
\hline Austria & 360 & 13377.2 & 37158.9 & 742.7 & 7.4 & 2.9 \\
\hline Belgium & 562 & 33732.6 & 60022.4 & 784.3 & 13.7 & 8.7 \\
\hline Bulgaria & 606 & 1455.4 & 2401.7 & 102.0 & 4.9 & 2.6 \\
\hline UK & 2826 & 36386.9 & 12875.8 & 411.7 & 5.2 & 3.4 \\
\hline Greece & 979 & 2150.6 & 2196.7 & 207.3 & 4.6 & 3.3 \\
\hline Denmark & 263 & 5362.0 & 20387.8 & 459.7 & 4.8 & 3.8 \\
\hline Estonia & 110 & 452.4 & 4112.7 & 191.7 & 3.8 & 2.2 \\
\hline Spain & 3409 & 37132.2 & 10892.4 & 422.9 & 8.0 & 4.7 \\
\hline Italy & 4312 & 49570.7 & 11496.0 & 459.1 & 5.6 & 2.9 \\
\hline Cyprus & 57 & 86.4 & 1515.8 & 138.5 & 2.8 & 2.1 \\
\hline Latvia & 231 & 218.3 & 945.0 & 76.7 & 2.8 & 2.4 \\
\hline Lithuania & 144 & 1774.8 & 12325.0 & 334.8 & 9.8 & 2.5 \\
\hline Luxembourg & 16 & 332.4 & 20775.0 & 296.8 & 2.5 & 3.3 \\
\hline Malta & 40 & 32.8 & 820.0 & 114.8 & 1.3 & 1.3 \\
\hline Netherlands & 893 & 43760.7 & 49004.1 & 989.5 & 13.6 & 6.4 \\
\hline Germany & 3121 & 160450.4 & 51409.9 & 472.1 & 7.7 & 4.6 \\
\hline Norway & 222 & 5585.2 & 25158.6 & 541.1 & 6.7 & 4.6 \\
\hline Poland & 2444 & 14960.5 & 6121.3 & 184.6 & 5.2 & 3.1 \\
\hline Portugal & 791 & 4319.4 & 5460.7 & 345.4 & 5.3 & 1.8 \\
\hline Romania & 851 & 2283.7 & 2683.5 & 101.6 & 3.0 & 1.9 \\
\hline Slovakia & 446 & 1657.1 & 3715.5 & 186.5 & 2.3 & 1.9 \\
\hline Slovenia & 206 & 1270.5 & 6167.5 & 198.0 & 4.8 & 3.3 \\
\hline Hungary & 663 & 5638.5 & 8504.5 & 373.1 & 5.5 & 2.0 \\
\hline Finland & 288 & 7686.3 & 26688.5 & 601.9 & 6.3 & 3.8 \\
\hline France & 3042 & 66628.6 & 21902.9 & 457.8 & 7.3 & 5.0 \\
\hline Croatia & 358 & 730.1 & 2039.4 & 124.4 & 3.6 & 2.2 \\
\hline Czech Republic & 1815 & 6142.6 & 3384.4 & 202.4 & 3.8 & 2.3 \\
\hline Sweden & 821 & 9438.9 & 11496.8 & 448.8 & 4.8 & 3.5 \\
\hline
\end{tabular}

Author's calculations by (State Statistics Service of Ukraine; Annual detailed enterprise statistics for industry, electronic resource) 
The ORLh per worker in Ukraine is in 2.7 times lower than in Latvia (the lowest value of this indicator among EU countries) and almost in 35 times - than in the Netherlands. By the share of chemical products in the volume of industrial products sold in 2016, Ukraine predominated only Luxembourg, Malta and Slovakia, and by the indicator of the share of workers engaged in the chemicals production - Bulgaria, Estonia, Malta and Slovakia.

Ukrainian chemical industry remains raw-oriented, determines the territorial concentration of basic chemical production, and, at the same time, determines the need for structural transformation of this sector in the direction of hightech industries increasing. However, such a transformation should foresee the need to preserve existing competitive advantages (raw material deposits and production capacities) that can be used to develop the chemical industry in the long term. Therefore, the priority for development in Ukraine should be those chemicals which are considered as raw materials and semi-finished products not only for the chemical but also for other sectors (light, food, etc.) industry, as well as other types of economic activity.

\section{Conclusions}

Summing up the results of the conducted research, low efficiency of Ukrainian chemical industry functioning, in particular, compared with the EU countries can be noted. Thus, the volumes of domestic chemical products production and export are in ten times smaller than in the EU-leading chemical manufacturing countries, and the turnover per one chemical company in Ukraine is significantly lower than in European countries. In addition, the dynamics of chemical production in the EU are characterized by much more stable tendencies, while the chemical industry of Ukraine, being export-oriented and, at the same time, import-dependent, directly depends on the state of the chemical products world market. On the other hand, the fact of active chemical production growth in Ukraine in 2016-2018, which in several times exceeded the figures in EU countries, gives grounds for the statement about the domestic chemical industry prospects.

In the context of the global chemical industry new architecture formation, a key guideline for the chemical companies development is the innovation, which confirms the need to intensify innovation activities in Ukraine. The main motivation to innovate is the demands of the market, that is, consumers of chemical products (sectors of the economy and the population) and pressure against competitors. The realization of such a task, for its part, requires:

- high-tech chemical production development stimulation through selective subsidization (increase of target state subsidies) on the example 
of the EU member states, preferential crediting and taxation, with increasing the knowledge of the products, giving preferences (additional points) in conducting tenders for the receipt of a state order, provided the values of the coefficient localization of internal potential at a certain level, involvement in the implementation of state target programs, etc .;

- creation of effective technological chemical industry development forecasting system (primarily with the participation of the institutes of the National Academy of Sciences of Ukraine) on the basis of constant monitoring of the technical re-equipment level.

In order to increase the competitiveness of the chemical industry in Ukraine, institutional reforms are called for, in particular, to promote:

- formation of vertically and horizontally integrated institutional structures for the production of chemical products with a full technological cycle (from raw materials to final products);

- creation of clusters, industrial (chemical) parks and other associations of industrial, scientific and commercial enterprises of various types of economic activity for the implementation of priority investment and innovation projects;

- stimulating the chemical enterprises participation in the formation of stable cooperative ties, ensuring inter-sectoral and interregional cooperation.

\section{References}

1. Heyets, V. M., \& Ostashko, T. O. (Eds.) (2016). Implementatsiia Uhody pro asotsiatsiiu mizh Ukrainoiu ta YeS: ekonomichni vyklyky ta novi mozhlyvosti [The implementation of the Association Agreement between Ukraine and the EU: Economic Challenges and Opportunities]. Scientific Report. Kyiv: Institute for Economics and Forecasting of the NAS of Ukraine [in Ukrainian].

2. State Statistics Service of Ukraine (2017). Official site of the State Statistics Service of Ukraine. Retrieved from: http://www.ukrstat.gov.ua [in Ukrainian].

3. UN Comtrade Database. - URL: https://comtrade.un.org

4. Amosha, O. I., Buleyev, I. P., \& Zaloznova, Yu. S. (Eds.) (2017). Promyslovist' Ukrayiny 2014-2016: nevykorystani mozhlyvosti, shlyakhy vidnovlennya, modernizatsiyi ta suchasnoyi rozbudovy [Industry of Ukraine 2014-2016: unused opportunities, ways of restoration, modernization and modernization]. Scientific Report. Kyiv: Institute of industrial economics of the NAS of Ukraine. [in Ukrainian]. 
5. Deyneko, O. T. (2018). Rozvytok promyslovosti dlya zabezpechennya zrostannya ta onovlennya ukrayins'koyi ekonomiky [Development of industry for growth and renewal of the Ukrainian economy]. Scientific Report. Kyiv: Institute for Economics and Forecasting of the NAS of Ukraine [in Ukrainian].

6. Shevtsova, H. Z., \& Shvets, N. V. (2017). Klasteryzatsiya khimichnoyi promyslovosti: yevropeys'kyy dosvid ta uroky dlya Ukrayiny [Clustering of the chemical industry: European experience and lessons for Ukraine]. Visnyk ekonomichnoyi nauky Ukrayiny - Herald of the Economic Sciences of Ukraine, 2, 103-109. [in Ukrainian].

7. Shevtsova, H. Z. (2017). Khimichna industriya 4.0 yak haluzeva kontseptsiya realizatsiyi osnov chetvertoyi promyslovoyi revolyutsiyi [Chemical Industry 4.0 as a branch concept for implementing the foundations of the Fourth Industrial Revolution]. Ekonomichnyy visnyk Donbasu - Economic herald of the Donbas, 2 (48), 35-41 [in Ukrainian].

8. Annual detailed enterprise statistics for industry // Eurostat. - URL:: http://appsso.eurostat.ec.europa.eu

9. Facts \& figures of the European chemical industry // Cefic, the European Chemical Industry Council. - URL:: https://cefic.org/app/uploads/2018/12/ Cefic_FactsAnd_Figures_2018_Industrial_BROCHURE_TRADE.pdf

10. The Frank R. Lautenberg Chemical Safety for the 21st Century Act // United States Environmental Protection Agency. - URL: https://www.epa.gov/ assessing-and-managing-chemicals-under-tsca/frank-r-lautenberg-chemicalsafety-21st-century-act

11. The state of the chemical industry 2016 review and 2017 outlook // Chemical\&Engineering news. - URL: https://www.ge.com/digital//p/statechemical-industry-2016-review-and-2017-outlook

12. Trends in the chemical industry. - URL: https://report.basf.com/2017/en/ managements-report/basf-group-business-year/economic-environment/ chemical-industry.html 